\title{
Spermospora ciliata (Sprague) Deighton and Scolecotrichum graminis Fuckel on Finnish grasses
}

\author{
Kaiho $M \ddot{a} k$ el $\ddot{a}$
}

\author{
Department of Plant Pathology, University of Helsinki
}

\begin{abstract}
The material (c. 3770 samples) for this study was collected from planted grasslands or the borders of fields throughout the country in 1966-1970. Collections of the Plant Pathology Department of Helsinki University were also examined.

Spermospora ciliata (Sprague) Deighton was found on 58 grass samples involving 11 grass species, most often on Festuca rubra L., from several localities ranging from Helsinki to Lapland.

Scolecotrichum graminis Fuckel was found on 28 grass samples involving 7 grass species, most often on Phleum pratense L., from southern Finland.
\end{abstract}

\section{Materials and methods}

Grass samples were collected during the period between spring thaw and the first heavy snowfall in autumn from 1966 to 1970 . The grasses (c. 3770 samples) were collected from planted grasslands and the borders of fields in many localities throughout the country (Fig. 1). Collections of the Plant Pathology Department of Helsinki University (HPP) were also examined. Conidia produced in natural infestations were examined. The slides of the fungus material were prepared from fresh grass leaves. The fungi on the slides were preserved in lactic-acid and lactophenol solutions with trypanblue. The conidia were also measured and photographed on the slides. The fungi were not grown in pure culture.

\section{Results and Discussion}

Spermospora Sprague, Mycologia 40: 177, 1948a. It is a genus of the order Moniliales and the family Moniliaceae (Sprague 1948a: 177).

Spermospora ciliata (Sprague) Deighton, Trans. Brit. Mycol. Soc. 51: 44, 1968; Syn.
Spermospora subulata Sprague forma ciliata Sprague, Mycologia 41: 495, 1949; Spermospora subulata (Sprague) Sprague, Mycologia 29: 202, 1937; Cercosporella subulata Sprague, Mycologia 29: 202, 1937. Sprague (1949) regards Spermospora subulata f. ciliata as a morphological form of. $S$. subulata, whereas Deigrton (1968) regards them as distinct species.

$S$. subulata was originally found on an herbarium specimen of Melica subulata (Griseb.) Scribn. (Sprague 1937). S. subulata f. ciliata was originally found on leaves of $\mathrm{Ag}$ rostis alba L. and Calamagrostis rubescentis Buckl. (Sprague 1949). The fungus has since been found on a large number of hosts e.g. on Agrostis stolonifera L., Bromus vulgaris (Hook.) Shear, Deschampsia caespitosa (L.) PB., Festuca rubra L., Phleum pratense L. and Poa trivialis L. in the USA, Canada and Britain (Sprague 1950, DeighTON 1968) as well as on Festuca rubra and Lolium perenne L. in New Zealand (LATcH 1966). The fungus is definitely parasitic, causing severe leaf scald, but it is never abundant (cf. Sprague 1948b, Deighton 1968). It is probably of little or no economic importance on grasses (cf. LATCH 1966). The 


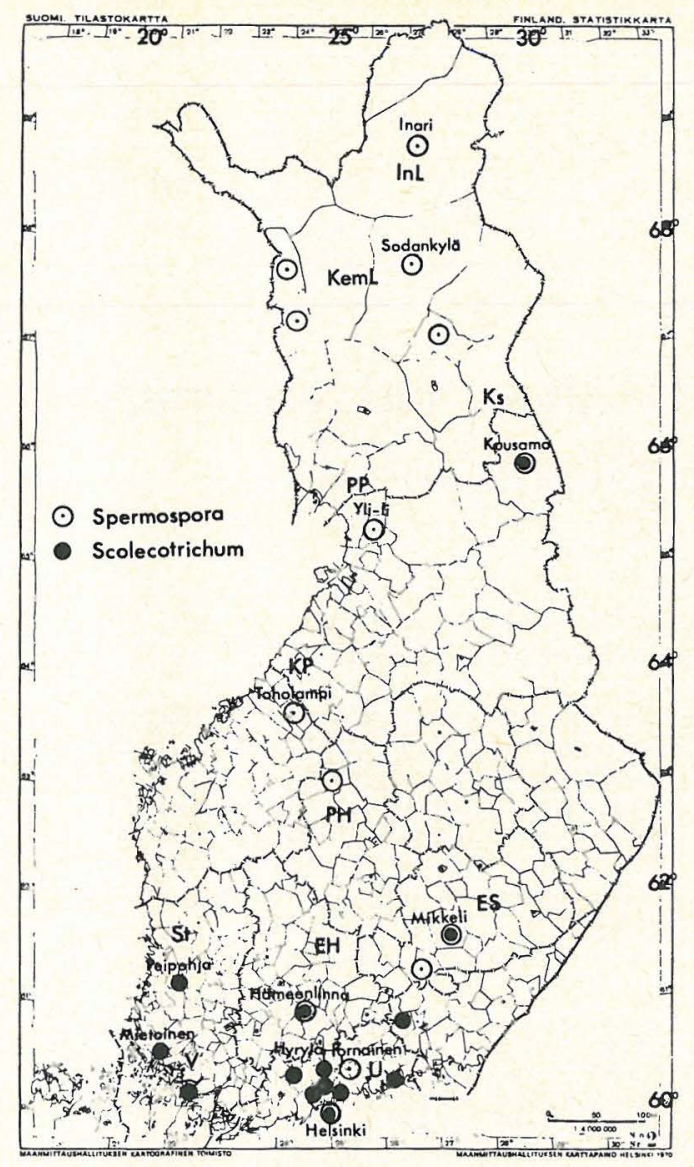

Fig. 1. Original of the material.

fungus has not been previously described in Finland. In the Collections of HPP there is only one sample: leg. Putkonen on Calamagrostis epigeios (L.) Roth. 9. VI. 1916, from Pornainen, in the province of Uusimaa (Fig. $3 \mathrm{G})$.

In the present study the fungus was found on 58 grass samples involving 11 grass species and from several localities ranging from Helsinki to Lapland (at Inari). Conidia of the fungus were found during the period between early spring (March), and late autumn (November). They were found least frequently in midsummer. As a rule conidia were found in small numbers. Also the material examined usually contained other fungi besides Spermospora (cf. Deighton 1968).

In the present study conidia of Spermospora spp. were observed in approximately $1.5 \%$ of the 3770 samples examined. The fungus was found most frequently (c. $16 \%$ ) on Festuca rubra at Viikki (Helsinki) (cf. MäKELÄ 1972). Lesions were especially distinct on leaves of Festuca rubra (Fig. 2 A) in spring and autumn. They varied from small spots to lesions covering large portions of the leaves and averaged (1) 3 (9) $\mathrm{mm}$ long and (0.5) $1-2 \mathrm{~mm}$ wide. Lesions were umbra to dark brown-black in colour with a white centre (Fig. $2 \mathrm{~F}$ ) and sometimes framed with yellow tissues (Fig. 2 A). Conidia were hyaline, subulate to subulate -filiform, tapering to a whip-like distal portion which was sometimes straight, usually curved or flexuous, $13-36 \mu$ long and about $0.3-4 \mu$ wide (Figs. 2, 3). Conidia narrowed gradually at the base towards the unthickened truncate hilum (Figs. 2 B, G, 3 C). The whole conidium (about 450 examined) including the rostrum was (28) 45.7 (76) $\mu$ long, (2) 3.9 (8) $\mu$ wide, (3) 3.9 (5) -septa. Material on Alopecurus pratensis had 3-septate spores (32) 38.7 (46) $\mu$ long, (3) 3.6 (4) $\mu$ wide; on Calamagrostis epigeios they were (20) 48.4 (71) $\mu$ long, (2) 4.9 (8) $\mu$ wide, 4 (5) -septa; on Dactylis glomerata (35) 51.5 (76) $\mu$ long, (3) 3.9 (5) $\mu$ wide, (3) (3.9) (5) -septa; on Deschampsia caespitosa (30) 44.8 (55) $\mu$ long, (2) 3.2 (4) $\mu$ wide, 4-septa; and on Festuca rubra (28) 44.9 (65) $\mu$ long, (2) 3.9 (5) $\mu$ wide, (3) 3.7 (5)-septa. The form and size of the conidia showed moderate variation between the different grasses (Figs. 2, 3). The size and the form of conidia resembled more those described by Sprague (1948a, b, 1949) than those described by Deighton (1968). In the present study conidia were in particular narrower and longer than those of the last mentioned.

Material examined (HPP):

On Agropyron repens:

U: Helsinki, Viikki 4. VI. 1968; EH: Hämeenlinna 25. V. 1969; ES: Mikkeli 21. V. 1968.

On Agrostis tenuis:

InL: Inari 28. VII. 1969.

On Alopecurus pratensis:

U: Helsinki, Viikki 18. XI. 1966, 20. XI. 1969; EH: Hämeenlinna 11. V. 1968; InL: Inari 17. VII. 1967, 13. VI. 1969 (leg. Salonen).

On Bromus inermis:

U: Helsinki, Viikki 22. X. 1968.

On Calamagrostis epigeios:

U: Pornainen 9. VI. 1916, leg. Putkonen; Helsinki 27. IX.1968; EH: Hämeenlinna 4. VII. 1970. 


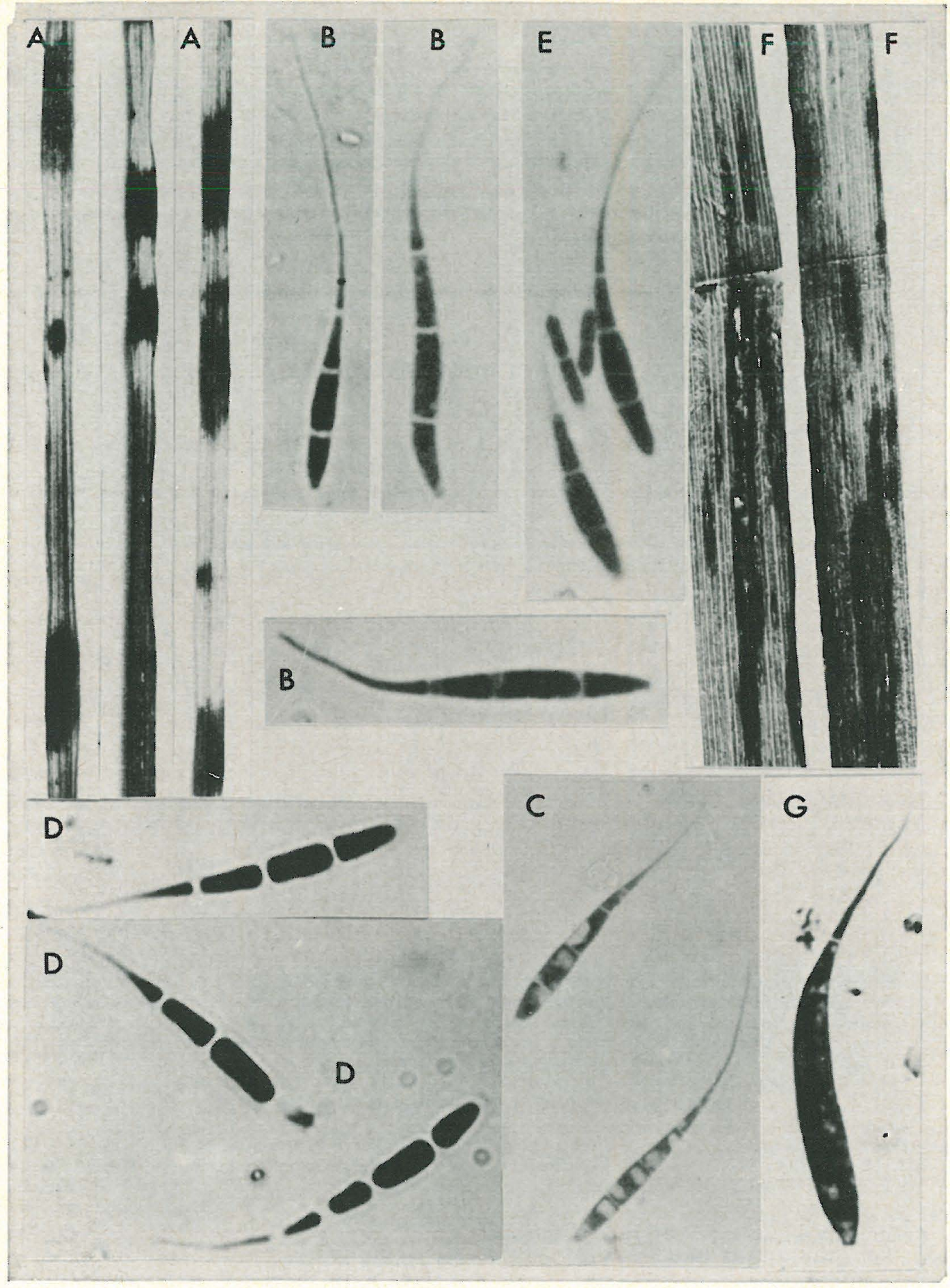

Fig. 2. Spermospora ciliata, A-D: on Festuca rubra, A-G: at Hämeenlinna, B: 11. V. 1968, C: 3. XI. 1968, D: at Inari 15. IX. 1969; E: on Alopecurus pratensis at Viikki 28. III. 1968; F, $\mathrm{G}$ : on Calamagrostis epigeros at Viikki 27. IX.1968. A, F: $\times 2$; B, C, E: $\times 1000 ; \mathrm{G}, \mathrm{D}: \times$ 2000. 

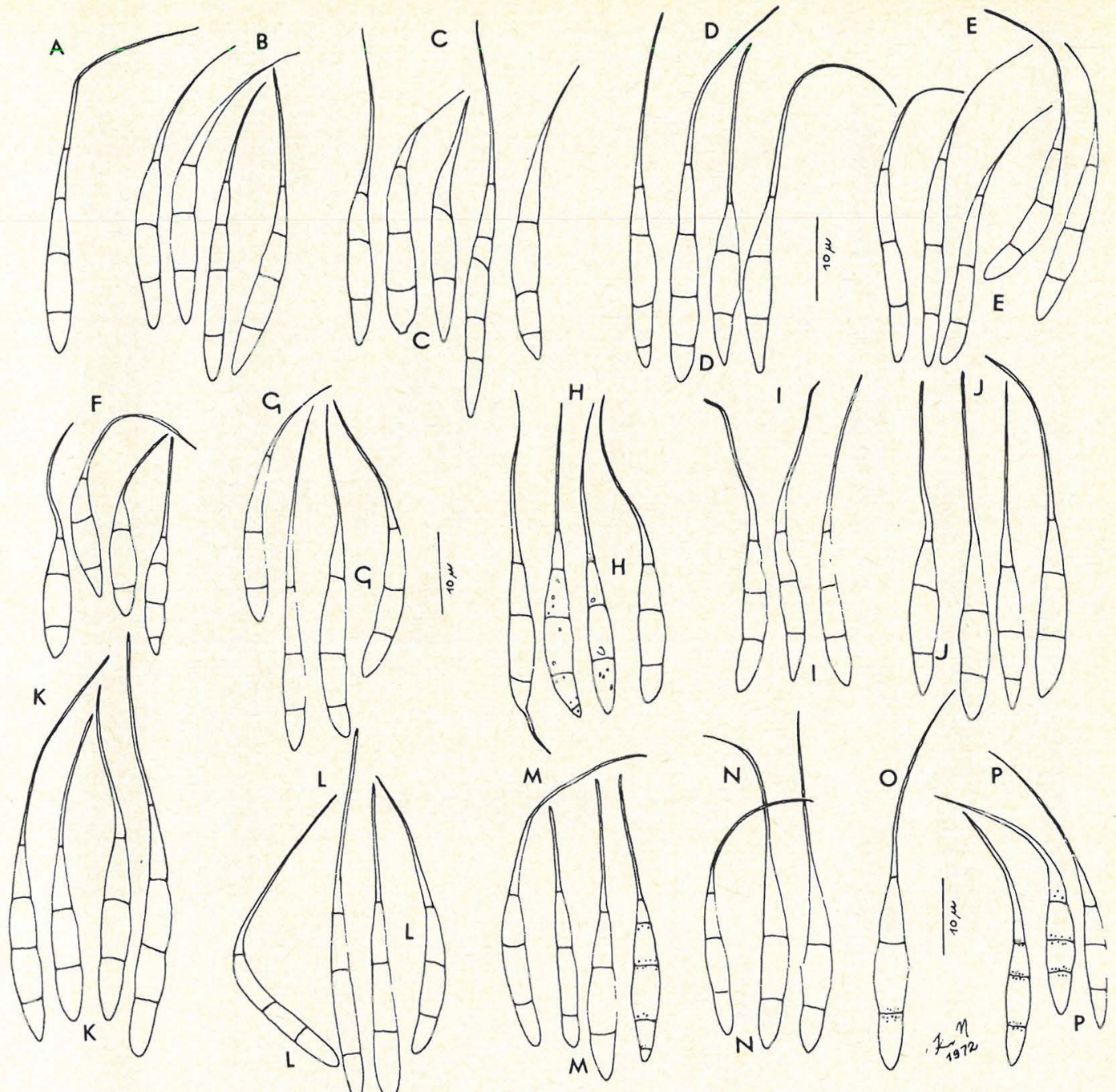

Fig. 3. Conidia of Spermospora ciliata, A: on Agrostis stolonifera at Viikki 11. XI. 1967; B: on Alopecurus pratensis in Hämeenlinna 11. V. 1968; C: on Calamagrostis epigeios, at Pornainen 9. VI. 1916; D: on Dactylis glomerata in Hämeenlinna 13. IV. 1968; E: on Deschampsia caespitosa at Inari 21. VII. 1968; F: on Festuca ovina at Inari 15. IX. 1969; G-M: on Festuca rubra; G: at Viikki 17. V. 1968; H, I: in Hämeenlinna, H: 13. IV. 1968, I: 3. XI. 1967; J: at Sodankylä 21. IX. 1966; K: at Kuusamo 21. IX.1966; L, M: at Inari, L: 22. VII. 1968, M: 15. IX. 1969; N: on Phleum pratense at Inari 20. VII. 1968; O, P: on Poa pratensis, O: in Hämeenlinna 11. V. 1968, P: at Inari 14. VII. 1969.

On Dactylis glomerata:

EH: Hämeenlinna 3. XI. 1967, 15. IV. 1968, 11. V. 1968; KP: Toholampi 10. VII. 1969.

\section{On Deschampsia caespitosa:}

KemL: Pelkosenniemi 21. VII. 1970 (leg. Ilonoja); InL: Inari 21. VII. 1968.

On Festuca ovina:

InL: Inari 15. IX. 1969 (leg. Salonen).

\section{On Festuca rubra:}

U: Helsinki, Viikki (13 specimens), Vantaa (1 specimen); EH: Hämeenlinna (6 specimens); ES: Mäntyharju (1 specimen); Mikkeli (1 specimen);
PH: Kivijärvi (1 specimen); PP: Yli-Ii (1 specimen); Ks: Kuusamo (1 specimen); KemL: Sodankylä (1 specimen), Kolari (1 specimen), Muonio (1 specimen); InL: Inari (4 specimens); in 1967 -1969; HPP.

\section{On Phleum pratense:}

U: Helsinki, Viikki 7.X. 1968; InL: Inari 20. VII. 1968.

On Poa pratensis:

U: Hyrylä 14. VII. 1970; EH: Hämeenlinna 11. V. 1968; InL: Inari 22. VII. 1968, 13. VI. 1969, 14. VII. 1969 (leg. Salonen). 
Scolecotrichum graminis Fuckel, Fungi Rhenani Exsiccati, Hedwigia 2: 134, 1863; Saccardo, Syll. Fung IV: 347-348, 1886; Syn. Passalora graminis (Fuckel) v. Höhnel, Centralbl. Bakt. Abt. 2, 60: 1-9, 1923 (cf. Sprague 1950: 427-428).

The fungus is the causal agent of a foliar disease of numerous grasses (about 160 species) throughout the world and particularly in Europe and the United States (LINDAU 1907: 795, Sprague 1950, Braverman 1958). Included in the host range are many forage species especially Phleum pratense L. and Dactylis glomerata L. (Bucholtz 1902, ERIKsson 1910, Mortensen et al. 1911, Lind 1913, JoHnson \& Hungerford 1917, Dennis \& Foister 1941 -42, Jørstad 1945, Sprague 1950, Roberts et al. 1955, Wenham \& Latah 1958, Elliott $1962)$. Sometimes $S$. graminis may be one of the most important of the pathogens which produce leaf spots on the grasses above mentioned (Melchers 1925, Brummer 1937, Sampson \& Western 1942, Sprague 1950). In many regions the fungus is less serious and develops saprophytically on many hosts on which it is only mildly parasitic (Jørstad 1930, 1945, Sprague 1950, Elliott 1962, LAtch 1966). Morphological variants of the fungus occur (Sprague 1950) as well as variants which differ in pathogenicity (BRAVERman 1958, Graham et al. 1963).

In Finland the fungus has been known to occur on Phleum pratense L. at least since 1927 and was common and economically very important in the 1930's in particular in fields being grown for seed production (BRummer 1937). The earliest sample of this fungus in the Collections of HPP is on Glyceria remota Fr. 23. VII. 1908 at Pernaja in Uusimaa, legg. Liro \& Ryselin. At the present time Scolecotrichum graminis occurs very infrequently and is rather insignificant (cf. MäKELÄ 1972).

In the present study the fungus was found on 20 grass samples involving 4 grass species from only a few localities. Cionidia of the fungus were found during the period between early spring (April) and late autumn (October). In midsummer, its occurrence was infrequent (cf. Bucholtz 1902, BRUMMER 1937). As a rule, the fungus was found in small numbers.

On grass leaves the fungus produces grey - greyish to orange - oak brown elongated streaks having golden yellow - apricot to bronze-brown borders in which the olive black tufts of conidiophores develop in parallel rows as minute dots along the surface (Fig. $4 \mathrm{~A}$ ). The conidiophores were (50$150 \times 5-10 \mu$ ) fasciculate, olive black, unbranched, irregular or slightly geniculate, sometimes thickened on the tip (Fig. 4 B, D, E). They may grow from little brown black, subepidermal stroma, especially in spring (Fig. 4 D, E) (cf. Braverman 1958). Conidia were light olive grey, elongate, bottle-shaped, base broadly rounded with prominent hilum (Fig. 4 B, C, F). The size of the conidia (about 200 examined) on Alopecurus geniculatus L., Phleum pratense L. and P. alpinum L. averaged (16) 37.9 (56) $\mu$ long, (4) 9.3 (12) $\mu$ wide and had (1) 2 (3) -septa. The size of conidia was nearly the same as in Sprague's (1950) material, but longer than those described by LINDAU (1907: 795) and Brummer (1937). Size and morphology of conidiophores, conidia and spores of isolates from different grasses did not differ significantly (cf. Braverman 1958). However, according to Sprague (1950) morphological variants have been found, but whether they are anything more than variations due to host and humidity is not known.

$$
\text { Material examined (HPP): }
$$

On Alopecurus geniculatus:

V: Parainen 18. VI. 1910, legg. Liro \& Linkola; U: Helsinki 13. X. 1970; St: Peipohja 15. V. 1968, 27. VI. 1968.

On Alopecurus pratensis:

U: Helsinki-5. VI. 1967; ES: Mikkeli 28. VI. 1968.

On Dactylis glomerata:

St: Peipohja 15. V. 1968.

On Glyceria fluitans:

U: Espoo 23. VII. 1923, legg. Liro \& AaltoSetälä.

On Glyceria remota:

U: Pernaja 23. VII. 1908, legg. Liro \& Ryselin.

On Phleum alpinum:

Ks: Kuusamo 17. VII. 1931, legg. Liro \& Heikinheimo.

\section{On Phleum pratense:}

U: Tammisto 1934 (4 specimens), leg. Brummer.

V: Mietoinen (3 specimens); U: Helsinki (3 specimens), Vihti 15. VIII. 1968; EH: Hämeenlinna (4 specimens), Iitti (2 specimens); St: Peipohja 15.V.1968; ES: Mikkeli 14.X. 1968; in 1966-1968, HPP. 


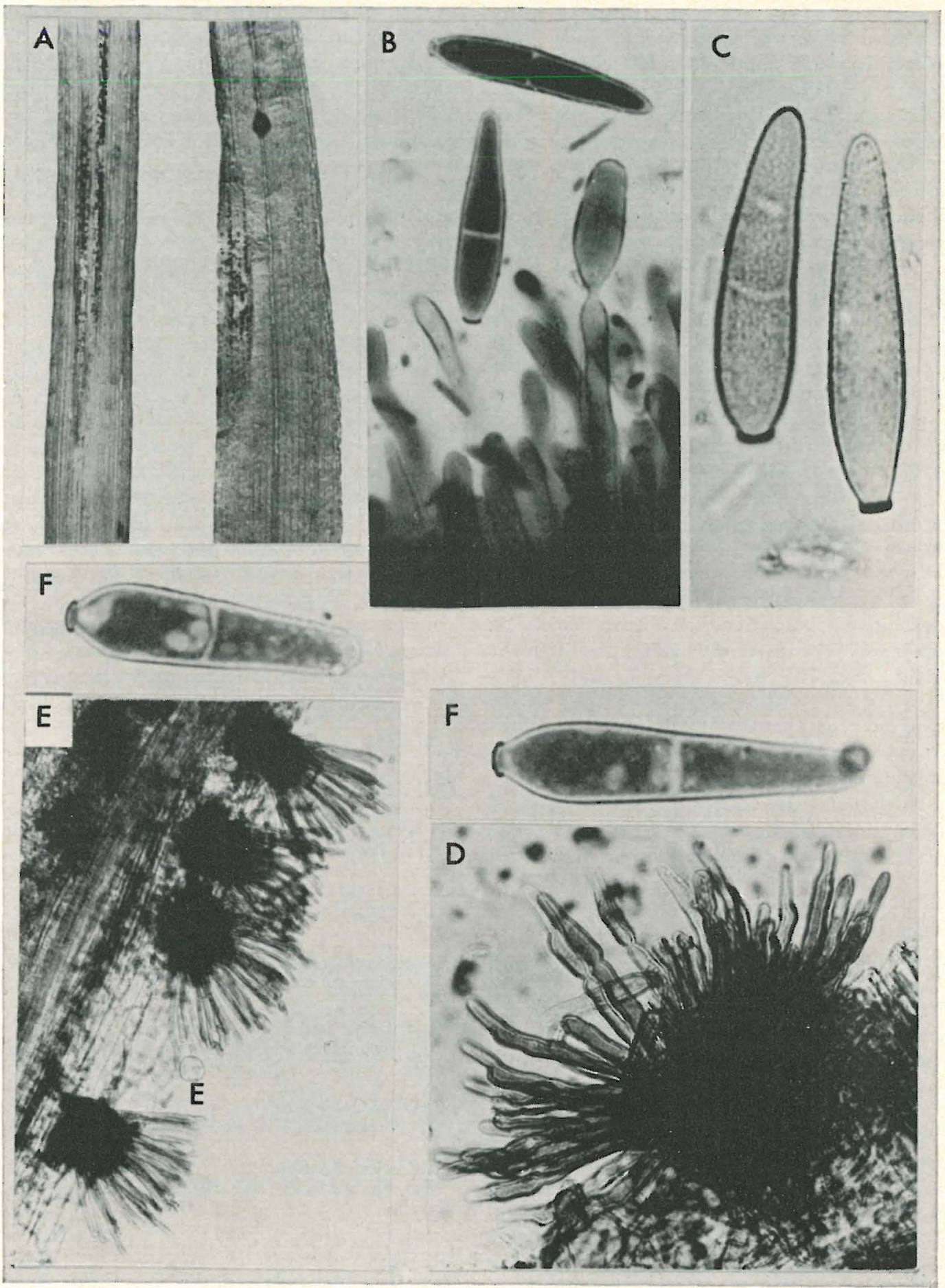

Fig. 4. Scolecotrichum graminis, A-D: on Phleum pratense, B, C: at Hämeenlinna, B: 31. X. 1969, G: 11. V. 1968; D: at Mietoinen 30. XI.1968; E, F: on Alopecurus geniculatus at Peipohja 27. VI. 1968. A: $\times 11 / 2, \mathrm{~B}: \times 1000 ; \mathrm{C}, \mathrm{F}: \times 2000 ; \mathrm{D}: \times 500 ; \mathrm{E}: \times 100$. 


\section{REFERENCES}

Braverman, S. W. 1958: Leaf streak of orchard grass, timothy, and tall oat grass incited by Scolecotrichum graminis. - Phytopathol. 48: $141-143$.

Brummer, V. 1937: Beobachtungen über die in Finnland auf dem Timothee auftretenden Pilzkrankheiten. - J. Sci. Agric. Soc. Finland 9: 165-180.

Bugholtz, F. 1902: Die Pilzparasiten des Sommers 1902 in der Umgebung von Riga. Z. Pflanzenkrankh. 13: $217-220$.

Deighton, F. C. 1968: Spermospora. - Trans. Brit. Mycol. Soc. 51: 41- 49.

Dennis, R. W. G. \& Foister, G. E. 1941-42: List of diseases of economic plants recorded in Scotland. - Trans. Brit. Mycol. Soc. 25: $266-306$.

Elliott, E. S. 1962: Disease damage in forage grasses. - Phytopathol. 52: 448 - 451.

ERIKSSON, J. 1910: Landtbruksväxternas Svampsjukdomar. - 210 pp. Stockholm.

Fuckel, L. 1863: Fungi Rhenani Exsiccati. Hedwigia 2: 134.

Graham, J. H., Zeiders, K. E. \& Braverman, S. W. 1963: Sporulation and pathogenicity of Scolecotrichum graminis from orchard grass and tall oat grass. - Plant Dis. Rep. 47: $255-256$

von Höhnel, F. 1923: Studies ueber Hyphomyceten. - Centralbl. Bakt. Abt. 2, 60: 126.

Johnson, A. G. \& Hungerford, G. W. 1917: Scolecotrichum graminis on timothy, orchardgrass and other grasses. (Abstr.) Phytopathol. 7: 69.

JøRSTAD, I. 1930: Beretning om plantesykdommer i land- og hagebruket. VI. Sykdommer på korn- og engvekster. - $84 \mathrm{pp}$. Oslo.

- 1945: Parasittsoppene på kultur- og nyttevekster i Norge. I. Sekksporesopper (Ascomycetes) og konidiesopper (Fungi imperfecti) - Medd. Stat. Plant Pathol. Inst. 142 pp. Oslo.

Latch, G. C. M. 1966: Fungous diseases on rye- grasses in New Zealand. - New Zealand J. Agric. Res. 9: 394-409.

Lind, J. 1913: Danish fungi as represented in the herbarium of E. Rostrup. - 650 pp. Copenhagen.

LindAU, G. 1907: Fungi imperfecti: Hyphomycetes in Rabenhorst, L. Kryptogamen-Flora von Deutschland, Oesterreich und der Schweiz. 1, 8, 852 pp. Leipzig.

Mäkel ̈̈, K. 1972: Disease damage to the foliage of cultivated grasses in Finland. - Acta Agralia Fennica 124, 1: 1-56.

Melchers, L.E. 1925: Diseases of cereals and forage crops in the United States in 1924. - Plant Dis. Rep., Suppl. 40: 106-191.

Mortensen, M. L., Rostrrup, S. \& Kølpin Ravn, F. 1911: Oversigt over landbruksplanternes sygdomme i 1910 . — Tidsskr. Landbr. Planteavl. 18: $317-356$.

Roberts, D. A., Sherwood, R. T., Fezer, K. D. \& Ramamurthi, C. S. 1955: Diseases of forage crops in New York, 1954. - Plant Dis. Rep. 39, 4: 316-317.

Saccardo, P. A. 1886: Sylloge Fungorum IV. 807 p. Patavii.

Sampson, K. \& Western, J.H. 1942: Diseases of British grasses and herbage legumes. 85 pp. Cambridge.

Sprague, R. 1937: Undescribed species of Cercosporella and Cercospora on certain grasses in Oregon and Washington. - Mycologia 29: $199-206$.

- 1948a: Some leaf spot fungi on western Gramineae. II. - Mycologia 40: 177-193.

- 1948b: Some leaf spot fungi on western Gramineae. III. - Mycologia 40: 295-313.

- 1949: Some leaf spot fungi on western Gramineae. IV. - Mycologia 41: 493-504.

- 1950: Diseases of cereals and grasses in North America. - 538 pp. New York.

Wenham, H. T. \& Latch, G. G. M. 1958: Fungal leaf spot diseases on cocksfoot (Dactylis glomerata L.) in the Manawatu. - New Zealand J. Agric. Res. 1: 800-808. 